\title{
Density of the eriophyid mites inhabiting the domatia of Cinnamomum camphora Linn. affects the density of the predatory mite, Amblyseius sojaensis Ehara (Acari: Phytoseiidae), not inhabiting the domatia
}

\author{
Atsushi Kasai, * Shuichi Yano and Akio Takafuji \\ Laboratory of Ecological Information, Graduate School of Agriculture, Kyoto University, Kyoto 606-8502, Japan \\ (Received 8 March 2002; Accepted 31 July 2002)
}

\begin{abstract}
We studied the seasonal occurrence of the eriophyid mites in the domatia of Cinnamomum camphora leaves and the predatory mite, Amblyseius sojaensis, near the domatia. The eriophyid mites increased in number in June, followed by an increase of $A$. sojaensis. The number of $A$. sojaensis near the domatia was significantly higher when the eriophyid mites were present in the domatia than when they were absent from it. When the domatia entrance was experimentally filled with glue to prevent the eriophyid mites from being preyed upon, the density of $A$. sojaensis was significantly reduced. These results showed that the density of the eriophyid mites that inhabit the domatia affect the density of the predatory mite, $A$. sojaensis, that do not inhabit the domatia.
\end{abstract}

Key words: Domatia, Cinnamomum camphora, Amblyseius sojaensis, eriophyid mites

\section{INTRODUCTION}

Microstructures of plants variously affect small arthropods inhabiting the plants (e.g. Damman, 1987; Larsson et al., 1997). One such structure is the domatia, the small space in the vein axil on the underside of leaves of woody angiosperms, which is typically inhabited by predatory or fungivorous mites (e.g. Pemberton and Turner, 1989).

Micro-phytophagous eriophyid mites are known to inhabit the domatia of Cinnamomum camphora Linn. (Pemberton and Turner, 1989). Preliminary observations showed the eriophyid mites (subfamily: Cecidophyinae, in identification) occurred in the domatia of C. camphora. These mites were seldom observed outside of the domatia. The predatory mite, Amblyseius sojaensis Ehara (Acari: Phytoseiidae), was observed near the domatia of $C$. camphora, but not inside it. The eriophyid mites collected from the domatia were preyed upon by $A$. sojaensis in the laboratory (Kasai, unpublished). Thus, it is plausible that the density of the eriophyid mites in the domatia may affect the density of $A$. sojaensis near the domatia. In this study, we report the seasonal occurrence of the eriophyid mites in the domatia and A. sojaensis near the do- matia, and the effect of the density of the eriophyid mites that inhabit the domatia on the density of a predatory mite, $A$. sojaensis, that does not inhabit it.

\section{MATERIALS AND METHODS}

Seasonal occurrence of the eriophyid mites in the domatia and $\boldsymbol{A}$. sojaensis near the domatia. In order to monitor the seasonal change in the abundance of the eriophyid mites in the domatia and that of $A$. sojaensis near the domatia, we sampled 1961 leaves at random from three individual C. camphora trees on the campus of Kyoto University once a month from April 2000 to March 2001. We counted the number of the eriophyid mites in the domatia under a stereomicroscope by dissecting the domatia, and the number of $A$. sojaensis near the domatia (radius of less than $1 \mathrm{~cm}$ ) with the unaided eye.

Effect of density of the eriophyid mites that inhabit domatia on the density of $A$. sojaensis that do not inhabit them. To examine the effect of the density of the eriophyid mites on the density of $A$. sojaensis, we conducted an experiment on a $C$. camphora tree on the campus of Kyoto University

\footnotetext{
* To whom correspondence should be addressed at: E-mail: ksi@kais.kyoto-u.ac.jp
} 
in September 2001. We randomly selected 120 shoots from the tree, and assigned them to one of the following three treatments: 1) the domatia entrance was filled with glue (woodworking bond, Konishi Corporation); 2) glue was smeared near the domatia entrance (radius of less than $1 \mathrm{~cm}$ ) to confirm whether the predators avoided the glue; 3 ) no treatment (control). There were 10.04 ( $\mathrm{SE}=$ 0.43 ) leaves per shoot on average. Forty replications were done for each treatment. We confirmed the presence of the eriophyid mites in the domatia prior to treatment. After 7 days, we counted the number of $A$. sojaensis near the domatia as described above.

\section{RESULTS}

Figure 1 shows the seasonal change in the density of the eriophyid mites and A. sojaensis on $C$. camphora. A. sojaensis was observed near the domatia, but was not observed inside the domatia. The density of eriophyid mites in the domatia showed a rapid increase from May to June, and decreased sharply thereafter. After August, the density remained low until the next spring. The density of $A$. sojaensis showed a sharp increase from May to June and then decreased abruptly by August following the same pattern as observed for the eriophyid mites. No $A$. sojaensis were observed after November. The density of $A$. sojaensis near the domatia was significantly higher when the eriophyid mites were present in the domatia than when they were absent in May and June (Table 1).

The number of $A$. sojaensis in treatment 1 (the domatia entrance was filled with glue) was significantly lower than that in each of the other two treatments (Fig. 2). The number of A. sojaensis did not differ between treatment 2 (glue was smeared near the domatia entrance) and treatment 3 (control). This indicates that the mites did not avoid the glue.

\section{DISCUSSION}

The hypotheses advanced to explain the function of the domatia assume that it may directly benefit predatory or fungivorous mites inhabiting them (e.g. O'Dowd and Willson, 1989, 1991; Walter and O'Dowd, 1992). Many studies on domatia have also been based on the hypothesis that plants ob-

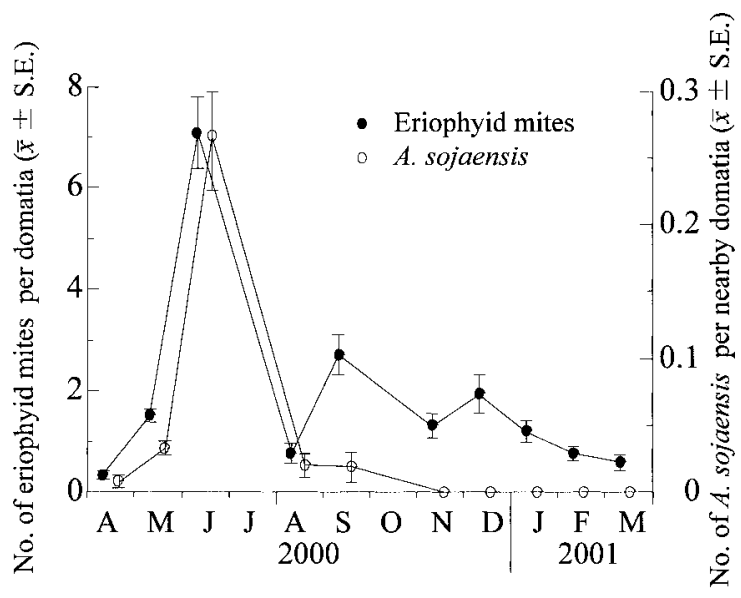

Fig. 1. Seasonal occurrence of the eriophyid mites per domatia and $A$. sojaensis per nearby domatia (radius of less than $1 \mathrm{~cm})$.

Table 1. The number of $A$. sojaensis per domatia ( $\pm \mathrm{SE})$ in relation to the presence of the eriophyid mites in the domatia

\begin{tabular}{|c|c|c|c|}
\hline \multirow{2}{*}{ Month } & \multicolumn{2}{|c|}{ Eriophyid mites } & \\
\hline & Absent & Present & \\
\hline Apr. 2000 & $0.009 \pm 0.005$ & $0 \pm 0$ & ns \\
\hline May 2000 & $0.024 \pm 0.005$ & $0.063 \pm 0.013$ & $* * *$ \\
\hline June 2000 & $0.112 \pm 0.030$ & $0.407 \pm 0.071$ & $* * *$ \\
\hline Aug. 2000 & $0.020 \pm 0.010$ & $0.020 \pm 0.020$ & ns \\
\hline Sep. 2000 & $0 \pm 0$ & $0.047 \pm 0.027$ & ns \\
\hline Nov. 2000 & $0 \pm 0$ & $0 \pm 0$ & - \\
\hline Dec. 2000 & $0 \pm 0$ & $0 \pm 0$ & - \\
\hline Jan. 2001 & $0 \pm 0$ & $0 \pm 0$ & - \\
\hline Feb. 2001 & $0 \pm 0$ & $0 \pm 0$ & - \\
\hline Mar. 2001 & $0 \pm 0$ & $0 \pm 0$ & - \\
\hline
\end{tabular}

*** Significant difference between absence and presence of the eriophyid mites $(p<0.001$ by ANOVA).

tain benefit from reduced herbivore or pathogen attack by being associated with the predatory or fungivorous arthropods (e.g. Grostal and O'Dowd, 1994; Agrawal, 1997; Agrawal et al., 2000; Norton et al., 2000). However, there has been no study on the effect of the density of the eriophyid mites that inhabit the domatia on the density of the predatory mite, A. sojaensis that do not inhabit the domatia.

The seasonal occurrence of $A$. sojaensis followed that of the eriophyid mites (Fig. 1). A. sojaensis near the domatia was much more abundant when the eriophyid mites were present in the domatia than when they were absent from it (Table 1). This suggests that the density of the eriophyid 


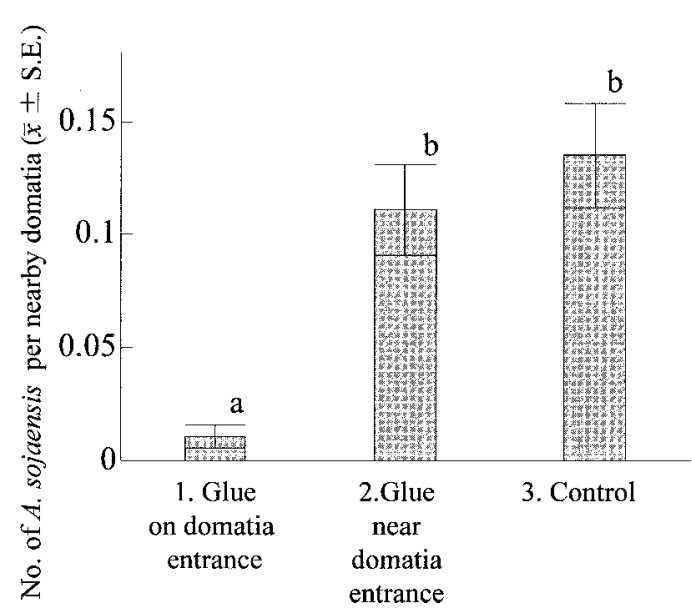

Fig. 2. The number of $A$. sojaensis per nearby domatia with 3 treatments. 1) the domatia entrance was filled with glue; 2) glue was smeared near the domatia entrance; 3) no treatment (control). Different letters indicate significant difference at 5\% level by Scheffé's post hoc test.

mites in the domatia affects the density of $A$. sojaensis near the domatia. In order to demonstrate this causal relationship, we experimentally controlled the availability of the eriophyid mites for $A$. sojaensis. The lower density of A. sojaensis in treatment 1 (domatia entrance was filled with glue) may reflect that these predatory mites could not prey upon the eriophyid mites inhabiting domatia as food (Fig. 2). Since A. sojaensis cannot pass through the narrow entrance of the domatia, $A$. sojaensis may prey upon only the eriophyid mites that disperse from the domatia. The timing and amount of the eriophyid mites dispersing from the domatia should be clarified in the future.

The present study demonstrated that the density of the eriophyid mites that inhabit the domatia of C. camphora affects the density of the predatory mite, A. sojaensis that does not inhabit the domatia. However, further information on the life history of $A$. sojaensis remains to be examined in the future, such as whether or not A. sojaensis preys solely upon the eriophyid mites, and how A. sojaensis come through the season when the eriophyid mites are absent.

\section{ACKNOWLEDGEMENTS}

I thank Dr. F. Kadono of Chiba Prefectural Agriculture Research Center for the identification of the eriophyid mites. I also thank Dr. T. Nishida and Dr. S. Oku of Kyoto University for valuable suggestions on this study, and Dr. H. Amano of Chiba University for the identification of the phytoseiid mites.

\section{REFERENCES}

Agrawal, A. A. (1997) Do leaf domatia mediate a plant-mite mutualism? An experimental test of the effect on predators and herbivores. Ecol. Entomol. 22: 371-376.

Agrawal, A. A., R. Karban and R. G. Colfer (2000) How leaf domatia and induced plant resistance affect natural enemies and plant performance. Oikos 89: 70-80.

Damman, H. (1987) Leaf quality and enemy avoidance by the larvae of a pyralid moth. Ecology 68: 88-97.

Grostal, P. and D. J. O'Dowd (1994) Plants, mites and mutualism: leaf domatia and the abundance and reproduction of mites on Viburnum tinus (Caprifoliaceae). Oecologia 97: 308-315.

Larsson, S., H. Haggstrom and R. F. D. Denno (1997) Preference for protected feeding site by larvae of the willowfeeding leaf beetle Galerucella lineola. Ecol. Entomol. 22: 445-452.

Norton, A. P., G. English-Loeb, D. Gadoury and R. C. Seem (2000) Mycophagous mites and foliar pathogens: leaf domatia mediate tritrophic interactions in grapes. Ecology 81: 490-499.

O'Dowd, D. J. and M. F. Willson (1989) Leaf domatia and mites on Australasian plants: ecological and evolutionary implications. Biol. J. Linn. Soc. 37: 191-236.

O'Dowd, D. J. and M. F. Willson (1991) Associations between mites and leaf domatia. Trends Ecol. Evol. 6: 179-182.

Pemberton, R. W. and C. E. Turner (1989) Occurrence of predatory and fungivorous mites in leaf domatia. Am. J. Bot. 76: 105-112.

Walter, D. E. and D. J. O'Dowd (1992) Leaf morphology and predators: effect of leaf domatia on the abundance of predatory mites (Acari: Phytoseiidae). Environ. Entomol. 21: $478-484$. 